\title{
CORRIGENDUM
}

\section{Sustained induction of neuronal addition to the adult rat neostriatum by AAV4-delivered noggin and BDNF}

\author{
A Benraiss, E Bruel-Jungerman, G Lu, AN Economides, B Davidson and SA Goldman
}

Gene Therapy (2012) 19, 582; doi:10.1038/gt.2011.182; published online 10 November 2011

Correction to: Gene Therapy (2012) 19, 483-493; doi:10.1038/ gt.2011.114; published online 15 September 2011

Since the online publication of this paper the authors have noticed that they omitted to mention support by the New York
State Stem Cell Research Program (NYSTEM) in the Acknowledgements section. 